\title{
PROBLEMATYCZNY POWRÓT DO ŹRÓDEŁ: NIEPOKALANE POCZĘCIE NAJŚWIĘTSZEJ MARYI PANNY W LITURGII UKRAIŃSKIEGO KOŚCIOŁA GRECKOKATOLICKIEGO
}

\author{
PROBLEMATIC RETURN TO SOURCES: \\ IMMACULATE CONCEPTION OF THE BLESSED VIRGIN MARY \\ IN THE LITURGY OF THE UKRAINIAN GREEK CATHOLIC CHURCH
}

\begin{abstract}
The article concerns one of the most important aspects of the Eastern Catholic Churches' life, which is their faithfulness to their own rite, that is, a liturgical, theological, spiritual, and disciplinary heritage (c. $28 \S 1$ of The Code of Canons of the Eastern Churches). The Magisterium of the Church, from the documents of the Second Vatican Council to the edition in 1996 by the Congregation for the Oriental Churches of The Instruction for the Application of the Liturgical Prescriptions of the Code of Canons of the Eastern Churches, urges these communities to rediscover the richness of their traditions, and if necessary, to prudently remove foreign borrowings and return to the sources. The example of the holiday celebrated in the Christian East on December 9 shows how difficult this process is in the Ukrainian Greek Catholic Church. The Roman reform of liturgical books (1940s), which restored the name and liturgy of the Byzantine feast: The Conception of St. Anne, when she conceived The Holy Mother of God, changed in 1891 , is still waiting for full reception and implementation.
\end{abstract}

Key words: Eastern Catholic Churches; Latinization; liturgical reform; Congregation for the Oriental Churches; liturgical year.

W adhortacji apostolskiej Ecclesia in Europa z 28 czerwca 2003 r. Jan Paweł II dwukrotnie pisze o Katolickich Kościołach Wschodnich. W części adhortacji poświęconej dążeniom ekumenicznym, „świadomy nieuniknionych trudności”, zachęca wszystkich „do uznania i docenienia w duchu miłości i braterstwa wkładu, jaki mogą wnieść w konkretne budowanie

Ks. mgr lic. BogdAn PAŃCZAK - doktorant na Sekcji Liturgiki i Homiletyki w Instytucie Nauk Teologicznych KU, studiował w Papieskim Instytucie Wschodnim w Rzymie, wicerektor Metropolitalnego Greckokatolickiego Seminarium Duchownego w Lublinie; adres do korespondencji: ul. Prymasa Stefana Wyszyńskiego 6, 20-105 Lublin; e-mail: b.panczak@poczta.onet.pl 
jedności Katolickie Kościoły Wschodnie przez samą swoją obecność, bogactwo tradycji, świadectwo «jedności w różnorodności», inkulturację urzeczywistnioną w głoszeniu Ewangelii, różnorodność obrzędów"1. Drugie odniesienie znajduje się w części dokumentu poświęconej „Ewangelii nadziei dla nowej Europy” i dotyczy „wymiany darów między wspólnotami o różnej historii i tradycjach”. Ponownie rozbrzmiewa wezwanie: „Szczególnie docenić należy wkład tradycji kulturowej i duchowej, jaki wnoszą Katolickie Kościoły Wschodnie"2. Po piętnastu latach, w obliczu masowej emigracji, w wyniku której od kilku lat w państwach środkowej i zachodniej Europy zjawiły się setki tysięcy wschodnich katolików, nie tylko z Ukrainy, ten aspekt adhortacji stał się szczególnie aktualny.

\section{INTEGRALNOŚĆ TOŻSAMOŚCI I AUTENTYCZNOŚĆ TRADYCJI}

Zachęta do odkrycia potencjału tkwiącego w Katolickich Kościołach Wschodnich, wyartykułowana $\mathrm{w}$ jednym $\mathrm{z}$ ostatnich dokumentów podpisanych przez Jana Pawła II, była, z punktu widzenia dążeń do odbudowania jedności kontynentu europejskiego po dziesięcioleciach panowania totalitarnych reżimów, jedną z najistotniejszych cech pontyfikatu papieża z Polski. Korzeni takiego podejścia należy szukać w osobistych doświadczeniach Świętego. Na początku listopada 1972 r., spotykając się przy okazji wizytacji parafii św. Katarzyny w Krakowie ze wspólnotą greckokatolicką, arcybiskup Karol Wojtyła, w nawiązaniu do Soboru Watykańskiego II i celebrowanych podczas jego obrad liturgii w różnych obrządkach, powiedział: „Znam też waszą liturgię. Wiem, że ona jest bardzo piękna, jakże głęboka, jak przejmująca. Ją znam i podziwiam”. Dwukrotnie przywoławszy słowa Jezusa: „Nie lękajcie się”, kardynał mówił: „Chociaż jesteście tutaj w Krakowie małą Wspólnotą katolicką, mieścicie się w kaplicy tego prastarego kościoła św. Katarzyny, jednak macie swoją świadomość, świadomość swojej wspólnoty, swego posłannictwa, wielkiej tradycji, wielkiego znaczenia Dzieła, które leży u początków waszego Kościoła. Ja też mam tę świadomość. Trzeba, żeby to dzieło trwało, żeby to dzieło w dalszym ciągu się rozwijało"3.

\footnotetext{
${ }^{1}$ JAN PAWE⿺ II, Adhortacja apostolska Ecclesia in Europa. O Jezusie Chrystusie, który żyje w Kościele, jako źródto nadziei dla Europy, nr 32.

${ }^{2}$ Tamże, nr 118.

${ }^{3}$ Przemówienie księdza kardynała Karola Wojtyty podczas wizytacji parafii greckokatolickiej w kościele św. Katarzyny w Krakowie, 1-5 listopada 1972 r., w: W. Mokry, Papieskie postania Jana Pawła II do Ukraińców, Kraków: Wydawnictwo „Szwajpolt Fiol” 2001, s. 177.
} 
Dokumentem w całości poświęconym znaczeniu tradycji Kościołów Wschodnich jest list apostolski Orientale lumen z 2 maja 1995 r. Napisany w stulecie listu Orientalium dignitas papieża Leona XIII, miał w zamyśle Jana Pawła II uświadomić katolikom, że jeśli „wierzymy, że czcigodna i starożytna tradycja Kościołów Wschodnich stanowi integralną część dziedzictwa Kościoła Chrystusowego”, to powinni oni ją poznawać, „by móc się nią karmić i przyczyniać się - każdy na miarę swoich sił - do budowania jedności”4. Katolicy wschodni, według Jana Pawła II, „zdają sobie sprawę, że wraz z braćmi prawosławnymi są żywymi nosicielami" ${ }^{5}$ tradycji Kościołów Wschodnich. W zakończeniu listu papież, przywołując Dekret o Kościołach Wschodnich Katolickich Orientalium Ecclesiarum Vaticanum II, stwierdza: „Wielokrotnie zostało powiedziane, że pełna jedność Katolickich Kościołów Wschodnich z Kościołem Rzymskim nie może dla nich oznaczać umniejszenia własnej specyfiki i autentyczności. Gdyby do tego doszło, Sobór Watykański II zachęca je do ponownego odkrycia swojej tożsamości”6.

Konkretną pomocą dla katolików wschodnich w ponownym odkrywaniu swojej specyfiki, autentyczności i tożsamości jest wydana w styczniu $1996 \mathrm{r}$. przez Kongregację Kościołów Wschodnich Instrukcja w sprawie stosowania przepisów liturgicznych Kodeksu Kanonów Kościołów Wschodnich ${ }^{7}$. Wydana sześć lat po promulgacji przez Jana Pawła II Kodeksu Kanonów Kościołów Wschodnich $^{8}$ zbiera poszczególne przepisy liturgiczne wszystkich Kościołów Wschodnich pozostających w pełnej komunii ze Stolicą Apostolską, rozproszone wśród różnych tekstów, w jeden usystematyzowany schemat, „by pomóc im w integralnej realizacji ich własnej tożsamości”9. Wśród celów, jakie stawia sobie Instrukcja, jest skłonienie do pełniejszego zgłębienia niezmierzonych bogactw autentycznych tradycji wschodnich, gorliwego ich strzeżenia i ukazywania wszystkim wierzącym oraz doprowadzenie do odzyskania, tam gdzie jest to niezbędne, wschodniej autentyczności litur-

${ }^{4}$ JAN PAWEŁ II, List apostolski Orientale lumen, 1.

${ }^{5}$ Tamże.

${ }^{6}$ Tamże, 21.

${ }^{7}$ CONGRegazione Per Le ChIESE ORIENTALI, Istruzione per l'applicazione delle prescrizioni liturgiche del Codice dei Canoni delle Chiese Orientali, Città del Vaticano: Libreria Editrice Vaticana, 1996; Tekst polski (fragmenty): Instrukcja $w$ sprawie stosowania przepisów liturgicznych Kodeksu Kanonów Kościołów Wschodnich (wyjątki), „Anamnesis” 1997, nr 11, s. 7-16.

${ }^{8}$ Enchiridion Vaticanum 12. Documenti ufficiali della Santa Sede compreso Codex Canonum Ecclesiarum Orientalium, Bologna: Edizioni Dehoniane Bologna 1992. Tekst polski: Kodeks Kanonów Kościołów Wschodnich, Lublin: Wydział Prawa, Prawa Kanonicznego i Administracji Katolickiego Uniwersytetu Lubelskiego, Wydawnictwo Archidiecezji Lubelskiej „Gaudium”, 2002.

${ }^{9}$ Istruzione, 5. 
gicznej, zgodnej z Tradycją, którą każdy Kościół Wschodni odziedziczył od Apostołów za pośrednictwem Ojców ${ }^{10}$.

Instrukcja przypomina naukę Soboru Watykańskiego II, wyrażoną w dekrecie o Katolickich Kościołach Wschodnich, o organicznym rozwoju jako jedynym kryterium wprowadzania zmian we własnych obrządkach i dyscyplinie. Soborowe wezwanie do powrotu do tradycji przodków tam, gdzie wschodni katolicy „na skutek okoliczności czasu lub postępowania osób niesłusznie się od nich oddalili" "11, znajduje aktualizację w nauczaniu Jana Pawła II, kilkakrotnie przywoływanym w Instrukcji. I tak 21 listopada 1987 r. w homilii podczas Boskiej Liturgii w obrządku ormiańskim papież przypomniał o zdecydowanej postawie „Stolicy Apostolskiej, którą potwierdził Sobór, prosząc Kościoły Wschodnie pozostające z nią w pełnej komunii, by z odwagą odkrywały na nowo swoje własne, autentyczne tradycje, przywracając, jeśli to konieczne, ich pierwotną czystość" ${ }^{12}$. A 14 sierpnia $1988 \mathrm{r}$. w homilii podczas Modlitwy kadzidła w obrządku aleksandryjsko-koptyjskim wezwał: „Nie przyjmujcie z nadmierną łatwością kryteriów kultury i tradycji, które nie są wasze, porzucając w ten sposób sobie właściwą wrażliwość. [...] Oznacza to potrzebę osadzenia każdej ewentualnej modyfikacji liturgicznej na fundamencie uważnego studium źródeł, na obiektywnej znajomości charakteru waszej kultury, na pielęgnacji tradycji wspólnej dla całego chrześcijaństwa koptyjskiego" "13. W części Instrukcji poświęconej reformie i odnowie liturgicznej potwierdzeniem słów o potrzebie odkrycia pełnej wierności wobec własnej tradycji liturgicznej i usunięciu tego, co naruszałoby jej autentyczność, są słowa Jana Pawła II skierowane 26 sierpnia 1989 r. do Synodu Katolickiego Patriarchatu Ormiańskiego: „Jeśli zatem trzeba będzie usuwać przypadkowe formy i naleciałości pochodzące $\mathrm{z}$ innych niż wasza tradycji liturgicznych czy paraliturgicznych, możliwe jest, że tak czyniąc będziecie musieli skorygować także niektóre $\mathrm{z}$ elementów pobożności ludowej"14. Oczywiście Instrukcja określa to zadanie jako delikatne i podkreśla, że należy je realizować z roztropnością, by nie wywołać zamętu w duszach ${ }^{15}$.

\footnotetext{
${ }^{10}$ Tamże.

${ }^{11}$ SOBÓR WATYKAŃSKi II, Orientalium Ecclesiarum, 6.

${ }^{12}$ Istruzione, 12.

13 Tamże, 21.

${ }^{14}$ Tamże, 18. W ukraińskim tłumaczeniu Instrukcji (Instrukcija zastosuvannia liturhijnych prypysiw Kodeksu Kanoniv Schidnych Cerkov, Lviv: Wydawnictwo „Svičado” 1998) zamiast „,usuwać przypadkowe” jest „przystosowywać obce”, co uczyniło papieską wypowiedź wewnętrznie sprzeczną, nadając jej głównej myśli sens przeciwny do zamierzonego.

${ }^{15}$ Tamże.
} 


\section{RZYMSKA KOREKTA NIEUZASADNIONYCH ZMIAN}

Odnośnie do roku liturgicznego i dokonanych w jego strukturze zmian Instrukcja oznajmia: „Jeśli w ostatnich czasach do kalendarzy Katolickich Kościołów Wschodnich zostały wprowadzone święta czy posty pochodzące z liturgii łacińskiej lub innych obcych liturgii, należy zadbać z duszpasterską roztropnością o przywrócenie kalendarzowi własnej struktury, eliminując elementy niespójne $\mathrm{z}$ duchem i naturą wschodniego dziedzictwa" ${ }^{\prime 16}$. W tym aspekcie życia liturgicznego wschodnich katolików mamy przykład „eliminującej" interwencji Stolicy Apostolskiej, która w przybliżeniu o ćwierć wieku wyprzedziła naukę Vaticanum II o potrzebie powrotu do tradycji przodków, tam gdzie się od niej oddalili ${ }^{17} .15$ stycznia 1938 r. papież Pius XI zaaprobował powołaną przez zebranie plenarne Kongregacji dla Kościoła Wschodniego trzyosobową watykańską komisję do spraw reformy greckokatolickich ksiąg liturgicznych ${ }^{18}$. Było to wynikiem uniemożliwiających wspólną pracę tarć między zwolennikami dwóch opcji w łonie Kościoła greckokatolickiego, które schematycznie można określić jako tendencję bizantynizującą i latynizującą. Efektem prac rzymskiej komisji była publikacja serii ksiąg liturgicznych pod nazwą Recensio Ruthena, przeznaczonych dla Kościoła metropolii lwowskiej i eparchii mukaczewskiej na Zakarpaciu ${ }^{19}$.

Jedną z decyzji rzymskiej komisji było przywrócenie nazwy i tekstów liturgicznych święta celebrowanego 9 grudnia. W tradycji bizantyńskiej to „Poczęcie św. Anny, gdy poczęła ona Najświętszą Bogurodzicę”. W Kościele greckokatolickim od Synodu lwowskiego w 1891 r. to święto nosiło nazwę „Niepokalane Poczęcie Najświętszej Bogurodzicy” i było obchodzone jak święta najwyższej rangi, z jednym dniem przedświęcia i poświąteczną oktawą. Alfonse Raes SJ, liturgista, profesor Papieskiego Instytutu Wschodniego, jeden z filarów rzymskiej komisji, jako powód decyzji o przywróceniu poprzedniej nazwy i liturgii święta podaje to, że „Dodatek” do Aktów Synodu z 1891 r., w którym opublikowano nową służbę święta, nie był przez Synod z 1891 r. przyjęty i jako taki nie ma mocy prawnej ${ }^{20}$. Wymieniony

\footnotetext{
${ }^{16}$ Tamże, 36.

${ }^{17}$ Zob. SOBÓR WATYKAŃSKi II, Orientalium Ecclesiarum, 6.

${ }^{18}$ SaCra Congregazione Per la Chiesa Orientale, Oriente cattolico. Cenni storici e statistiche, Città del Vaticano 1962, s. 64.

${ }^{19}$ Ostatnim słowem o całej kwestii jest gruntowna praca kanadyjskiego badacza Petera Galadzy - zob. P. GaladZA, The Theology and Liturgical Work of Andrei Sheptytsky (18651944), (Orientalia Christiana Analecta 272), Roma: Pontificio Istituto Orientale 2004.

${ }^{20}$ A. RAES, Le liturgicon ruthène depuis l Union de Brest, „Orientalia Christiana Periodica” 7 (1942), № 1-2, s. 127.
} 
defekt był natury prawnej i można sobie wyobrazić jakąś formę sanowania całej sytuacji. W istocie decyzja dotycząca święta z 9 grudnia została podjęta zgodnie z duchem rzymskiej reformy, która - na miarę posiadanej wówczas wiedzy - zmierzała do odrodzenia autentycznych tradycji liturgicznych wschodnich katolików, wywodzących swój rodowód z tradycji kijowsko-halickiej.

Tak samo odzwierciedleniem stanu greckokatolickiej teologii z końca XIX wieku było przekonanie, wyrażone w „Dodatku”, że „chociaż nauka o niepokalanym poczęciu Najświętszej Dziewicy Maryi wyraźnie zawarta jest w Tradycji kościelnej, szczególnie w księgach liturgicznych Kościoła Wschodniego, to jednak nie była sformułowana przez Kościół jako dogmat aż do decyzji świętej pamięci papieża Piusa IX" ${ }^{21}$. Wymienia się następnie kilka przykładów z hymnografii różnych świąt, zarówno maryjnych, jak i niektórych świętych, na potwierdzenie tej tezy ${ }^{22}$. Wybitny znawca problematyki dogmatu z 1854 r., po przeanalizowaniu greckich źródeł, stwierdza jednak, ,że faktem zasługującym na uwagę jest to, iż teksty liturgiczne, wychwalając Przeczystą najwznioślejszymi określeniami, rzadko dostarczają formuł odpowiednich do nauki o niepokalanym poczęciu. Prawie zawsze są szerokie i nieokreślone" ${ }^{23}$. Należy także pamiętać, że epitety maryjne dotyczą przede wszystkim cielesnego dziewictwa Maryi i nie mają nic wspólnego z nauką o niepokalanym poczęciu. Nie można również nadawać zbyt wielkiej wagi teologicznej epitetom określającym Maryję jako przenajświętszą i przeczystą, gdyż grecka liturgia w takiej samej mierze obdarza nimi innych. Na przykład 24 listopada św. Cecylia określana jest jako „najświętszy przybytek Chrystusa”, „przeczysta świątynia Chrystusa”, „boski sad Pana"24.

Współczesny teolog przestrzega, by bizantyńskiej poezji greckiej, ze wszystkimi jej rodzajami obrazowania, typologią, alegorią, wyszukanymi figurami retorycznymi, a wśród nich hiperbolami, nie interpretować jakby były soborowymi kanonami dogmatycznymi ${ }^{25}$. Inny autor mówi wręcz, że wobec trudności z określeniem, czy zamiarem autorów hymnografii było wyłożenie doktryny, czy też wywołanie nabożnych uczuć u słuchaczy,

\footnotetext{
${ }^{21}$ Dodatok do čynnostej y riszen `ruskoho provincijalnoho sobora v Halyčyni otbuvšoho sja vo L'vovi wr. 1891, L'vov 1897, s. 47.

${ }^{22}$ Tamże, s. 48-49.

${ }^{23}$ M. JugIE, Immaculée conception, w: Dictionnaire de théologie catholique, red. A. Vacant, E. Mangenot, E. Amann, t. VII/1, Paris: Letouzey et Ané 1927, kol. 960.

${ }^{24}$ Tamże.

${ }^{25}$ R.F. TAFT, Liturgia. Wzór modlitwy, ikona życia, Warszawa: Wydawnictwo Księży Marianów PROMIC 2013, s. 215.
} 
„W studiach teologicznych hymnografii poświęca się mniej uwagi niż homiletyce" ${ }^{26}$.

Autorem nowego oficjum ku czci Niepokalanego Poczęcia Najświętszej Bogurodzicy był ks. Izydor Dolnycki (1830-1924), uważany za najwybitniejszego greckokatolickiego liturgistę przełomu wieków. Analiza tekstu stworzonej przezeń liturgii jednoznacznie prowadzi do wniosku, że głównym celem i troską autora było jak najmocniejsze podkreślenie i wysławienie prawdy o niepokalanym poczęciu. W hymnografii dwadzieścia razy explicite przekazana zostaje istota dogmatu z 1854 r. Dolnycki wykorzystał fragmenty z różnych tradycji liturgicznych: rzymskiej, bizantyńskiej, syryjskiej, chaldejskiej i ormiańskiej. W efekcie ta „powstała w pewnym pośpiechu służba”, chociaż ma zewnętrzne ramy typowe dla wschodniej liturgii, „wywołuje wrażenie wyrastania $\mathrm{z}$ łacińskiego liturgicznego korzenia, z zewnętrzną pstrokatą otoczką urywków z analogicznych służb innych Katolickich Kościołów Wschodnich"27.

\section{DŁUGIE TRWANIE}

Rzymska reforma ksiąg liturgicznych, uwieńczona ukazaniem się Recensio Ruthena, praktycznie zbiegła się w czasie z najcięższą próbą, jaką Kościół greckokatolicki przeszedł w swojej historii. Represje, którym od 1944 r. został poddany w Związku Sowieckim, doprowadziły do tego, że do końca lat 80. XX wieku jego istnienie polegało na funkcjonowaniu w podziemiu. Niewiele lepiej wyglądała sytuacja w tej części eparchii przemyskiej, która po zmianie granic weszła do składu Polskiej Rzeczypospolitej Ludowej. W warunkach walki o fizyczne przetrwanie, bez jakichkolwiek możliwości działania w sferze edukacyjnej, badawczej i wydawniczej, trudno było oczekiwać recepcji rzymskich zmian. Niezbędne minimum, jakie polegało na wydaniu ukraińskich przekładów liturgii eucharystycznych i innych sakramentów, stało się możliwe dzięki działalności zwolnionego po osiemnastu latach spędzonych w radzieckich łagrach zwierzchnika Ukraińskiego Ko-

${ }^{26}$ Ch. HANNICK, The Theotokos in Byzantine Hymnography: Typology and Allegory, w: Images of the Mother of God. Perceptions of the Theotokos in Byzantium, red. M. Vassilaki, Aldeshot-Burlington: Ashgate Publishing 2005, s. 70, cyt. za: R.F. TAFT, Liturgia, s. 215.

${ }^{27}$ K. Korolevsky (Jean Charon), Rym i obrjadovo-liturhični dyskusï u Patrijaršij Kyïvs `kij Vselens 'kij Cerkvi miž dvoma Svitovymy vijnamy, red. D. Blažejovs'kyj, L'viv 2002, s. 151. (Ukraiński przekład La liturgia ed il rito praticati dai ruteni, studium historyczno-kanonicznego napisanego przez francuskiego znawcę Wschodu dla Kongregacji dla Kościoła Wschodniego w 1938 r.). 
ścioła Greckokatolickiego kard. Josyfa Slipyja. W Rzymie, wokół stworzonego przez siebie centrum naukowego, skupił on kompetentnych kapłanów i świeckich i na miarę potencjału, jakim dysponowała wówczas greckokatolicka diaspora, dał swemu Kościołowi podstawowe księgi liturgiczne w żywym języku. Nazwa święta celebrowanego 9 grudnia była w nich zgodna $z$ decyzją rzymskiej komisji. Tak samo teksty hymnów śpiewanych podczas Boskiej Liturgii św. Jana Chryzostoma pochodziły ze święta Poczęcia św. Anny, gdy poczęła ona Najświętszą Bogurodzicę.

Dopiero na przełomie lat 80. i 90. XX wieku zjawiła się księga w języku ukraińskim, zawierająca teksty oficjum Liturgii Godzin. Pionierskie i pod wieloma względami cenne wydanie ukazało się w Wydawnictwie Zakonu Bazylianów w Rzymie i w Toronto ${ }^{28}$. Pod datą 9 grudnia znajduje się tam nazwa święta: „Niepokalane Poczęcie Najświętszej Maryi Panny”, a pod nią w nawiasie: „Poczęcie świętej Anny”. Teksty wieczerni i jutrzni są przekładem z języka cerkiewnosłowiańskiego hymnografii stworzonej przez Izydora Dolnyckiego. We wstępie do Molytvoslova ówczesny protoarchimandryta Zakonu Bazylianów Izydor Patryło napisał, że poprzednie, powielane na cyklostylu, wersje (od 1975 r.) rozeszły się w diasporze, zarówno katolickiej, jak i prawosławnej, w nakładzie pięciu tysięcy ${ }^{29}$. Protoarchimandryta stwierdza: „Chociaż wydanie tego Molytvoslova nie jest oficjalne, to będzie jednym z naszych większych liturgicznych osiągnięć w ostatnich latach oraz jedną z lepszych pamiątek naszego chrześcijańskiego Tysiąclecia. Mamy nadzieję, że w niedalekiej przyszłości stanie się ono podstawą dla doskonalszego i już oficjalnego wydania"30.

Zignorowanie przez bazyliańskich wydawców decyzji rzymskiej komisji ma swoją prahistorię. Po ukazaniu się Recensio Ruthena z urzędu rektora Papieskiego Kolegium św. Jozafata w Rzymie odwołano bazylianina o. Dionizego Holovetskiego, który odmówił zaakceptowania reformy. Tak samo sprzeciwił się jej ówczesny archimandryta Zakonu Bazylianów. Można rzec, że przykład szedł z góry, gdyż zrobili to także dwaj biskupi ordynariusze: przemyski Jozafat Kocyłowski i stanisławowski Grzegorz Chomyszyn ${ }^{31}$.

Po dziś dzień doskonalsze i oficjalne wydanie Molytvoslova nie ukazało się. Wersja z 1990 r. była wznawiana i praktycznie stała się podstawową księgą liturgiczną zawierająca Liturgię Godzin. W praktyce Kościoła tradycji bizantyńskiej oznacza to szerokie wykorzystanie w życiu liturgicznym

\footnotetext{
${ }^{28}$ Molytvoslov, Rym-Toronto: Vydavnyctvo OO. Vasylijan 1990.

${ }^{29}$ Tamże, s. 5.

${ }^{30}$ Tamże, s. 6.

${ }^{31}$ P. GaladZA, The Theology and Liturgical Work of Andrei Sheptytsky, s. 431.
} 
każdej parafii. Choć Kościół greckokatolicki na Ukrainie ponad ćwierć wie$\mathrm{ku}$ funkcjonuje już w całkowitej wolności, to w dziedzinie wydań ksiąg liturgicznych panuje niezrozumiały impas.

O trudnościach z recepcją rzymskiej reformy w aspekcie święta celebrowanego 9 grudnia można mówić nie tylko w odniesieniu do Zakonu Bazylianów. Katechizm Ukraińskiego Kościoła Greckokatolickiego (UKGK) „Chrystus - nasza Pascha” naucza: „Ze świętem Narodzenia Bogurodzicy związane jest święto Poczęcia św. Anny, gdy poczęła Najświętszą Bogurodzicę albo Niepokalane Poczęcie Najświętszej Bogurodzicy (9/22 grudnia) - dziewięć miesięcy przed jej Narodzeniem"32. A w partykularnym prawie UKGK kanon $114 \S 3$ mówi o tym, że wiernych zachęca się do udziału w święcie „Niepokalane Poczęcie Najświętszej Bogurodzicy przez św. Annę"33.

W Internecie w zasadzie do wyjątków należą strony, na których 22 grudnia (według kalendarza juliańskiego stosowanego przez UKGK) używa się prawidłowej nazwy święta. Jeszcze raz można rzec, że przykład idzie z góry. Na oficjalnej informacyjnej stronie UKGK w kalendarzu na 22 grudnia 2019 r. figuruje: Niepokalane Poczęcie Najświętszej Bogurodzicy ${ }^{34}$.

Wiara w niepokalane poczęcie Bogurodzicy charakteryzowała chrześcijan należących do Kościołów Wschodnich wywodzących się z tradycji kijowskiej. Cerkiew w Drelowie koło Drohiczyna, ufundowana przez łacinniczkę, otrzymała takie wezwanie w 1653 r. I choć tytuł był nowy, „nie przyjęto go jako innowacji”, gdyż i naukę, i tytuł cerkwi „odbierano jako wyrażające w pełniejszy sposób to, o czym mówiło stare wschodnie święto Poczęcia św. Anny”35. Uniccy bazylianie rozpoczynali swoje kapituły „Na chwałę Boga w Trójcy jedynego i Bogurodzicy Dziewicy niepokalanie poczętej”, temat niepokalanego poczęcia zjawia się $\mathrm{w}$ poezji prawosławnych autorów ${ }^{36}$, a prawosławni Rusini w Wilnie święto 9(22) grudnia obchodzili w o wiele bardziej uroczysty sposób, niż to było przewidziane w bizantyńskiej tradycji i normach liturgicznych ${ }^{37}$. Nie prowadziło to jednak do jakiejkolwiek inge-

\footnotetext{
${ }^{32}$ Katechyzm Ukraïns'koji Hreko-Katolyc 'koji Cerkvy „Chrystos - naša Pascha”, L’viv: Vydavnyctvo „Svičado” 2011, s. 576.

${ }^{33}$ Kanony Partykuljarnoho Prava Ukrä̈ns'koï Hreko-Katolyc'koï Cerkvy. Specvypusk „Blahovisnyka Verchovnoho Archyjepyskopa Kyjevo-Halyc'koho Ukrä̈nskö Hreko-Katolyc'koï Cerkvy 2015 roku”, Berezen' 2015, L'viv: Vydavnyctvo „Drukars'ki kunš'ty” 2015, s. 37.

${ }^{34} \mathrm{http}: / /$ news.ugcc.ua/calendar/2019-12/(dostęp 20.03.2019).

${ }^{35}$ S. SENYK, Marian Cult in the Kievan Metropolinate, w: De cultu mariano saeculis XVIIXVII, Romae: Academia Mariana Internationalis 1988, s. 521.

${ }^{36}$ Tamże.

${ }^{37}$ Tamże, s. 528.
} 
rencji w treść własnej liturgii. Stało się tak dopiero pod koniec XIX wieku, oczywiście w kontekście ogłoszonego w 1854 r. dogmatu.

Sprzeciw ze strony bazylianów, części hierarchii i duchowieństwa wobec rzymskiej reformy bezpośrednio po jej ogłoszeniu można starać się zrozumieć. Choć wiele na lepsze zmieniło się w traktowaniu przez łacińską katolicką większość chrześcijańskiego Wschodu od listu Leona XIII Orientalium dignitas, to wtłaczane od dokładnie dwustu lat (Etsi pastoralis Benedykta XIV z 1742 r.) przekonanie o „praestantia ritus latini” nie mogło zniknąć $\mathrm{z}$ dnia na dzień.

Z ogromnym trudem można próbować usprawiedliwić wydawców Molytvoslova. Działali już przecież w epoce po Soborze Watykańskim II. W żaden sposób nie da się zaś rozgrzeszyć tych, którzy dziś ignorują podjęte przez rzymską komisję dla ich eklezjalnego dobra decyzje. Nie tylko zwlekają z wcieleniem w życie wydanej przez Kongregację Kościołów Wschodnich Instrukcji. Nie wsłuchują się w to, co w kontekście odnowienia jedności chrześcijan mówi biskup Rzymu: „Z perspektywy dnia dzisiejszego widzimy, że prawdziwe zjednoczenie jest możliwe pod warunkiem pełnego poszanowania godności drugiego oraz odrzucenia tezy, jakoby całość zwyczajów i praktyk Kościoła łacińskiego była bardziej kompletna lub lepiej ukazywała pełnię poprawnej doktryny"38.

W adhortacji Ecclesia in Europa Jan Paweł II zachęca do uznania wkładu, jaki w konkretne budowanie jedności przez samą swoją obecność, bogactwo tradycji, świadectwo jedności w różnorodności, inkulturację urzeczywistnioną w głoszeniu Ewangelii, różnorodność obrzędów mogą wnieść Katolickie Kościoły Wschodnie. Tryb warunkowy powinien samym zainteresowanym dać do myślenia. $\mathrm{Na}$ ile ich obrzędy są autentyczne, jak żyją swoją liturgiczną i duchową tradycją? Sama obecność, często cechująca się hybrydową pod wieloma względami formą, to za mało. Mija trzydzieści lat od upadku w Europie komunistycznych reżimów, które praktycznie w każdym państwie, w którym istniał Kościół Wschodni w pełnej jedności ze Stolicą Apostolską w Rzymie, dążyły jeśli nie do jego całkowitej likwidacji, to co najmniej do marginalizacji. Czas odbudowy murów i struktur dobiega końca. Pora myśleć o najistotniejszym.

Życzliwi wschodnim katolikom ludzie Zachodu chcą im w tym pomóc. Jeden z najwybitniejszych znawców bizantyńskiej tradycji liturgicznej, wspominany już Robert Taft SJ (1932-2018) z naciskiem powtarzał, że jedynym powodem istnienia Katolickich Kościołów Wschodnich jako Eccle-

\footnotetext{
${ }^{38}$ Orientale lumen, 20.
} 
siae particulares sui iuris jest ich odrębne dziedzictwo, tzn. ich obrządek w pełnym tego słowa znaczeniu ${ }^{39}$. Amerykański jezuita miał na myśli kanon 28 Kodeksu Kanonów Kościołów Wschodnich, według którego obrządek jest „dziedzictwem liturgicznym, teologicznym, duchowym i dyscyplinarnym wyodrębnionym przez kulturę i okoliczności historyczne narodów, wyrażającym sposób przeżywania wiary, właściwy dla każdego Kościoła sui iuris”. Ten obrządek to nie tylko istotna część tożsamości wschodnich katolików, to po prostu ich tożsamość. I jeśli jedynym, co odróżnia wschodnich katolików od prawosławnych jest ich jedność ze Stolicą Apostolską w Rzymie i posłuszeństwo wobec niej, to uzasadnione, według Tafta, jest pytanie: „Jaka eklezjologia wschodniokatolicka mogłaby ignorować tak jasne i wielokrotnie powtarzane instrukcje Stolicy Apostolskiej w tym względzie"40. To paradoks, ale w łonie Ukraińskiego Kościoła Greckokatolickiego ,jasne i wielokrotnie powtarzane instrukcje" napotykają największy opór właśnie w tych środowiskach, które jedność z Rzymem i posłuszeństwo biskupowi tego miasta, obrazowo mówiąc, umieszczają na swoich sztandarach.

Byłoby przesadą twierdzić, że wszystko w Kościele zależy od kapłanów. Niemniej seminaria duchowne są miejscem, gdzie poprzez formowanie tożsamości przyszłych duszpasterzy kładzie się fundamenty pod przyszłość Kościoła. Świadom tego R. Taft nie odrzucał zaproszeń do takich instytucji. $\mathrm{Na}$ zakończenie rekolekcji wygłoszonych w 2008 r. dla alumnów ukraińskiego Seminarium św. Jozafata w Waszyngtonie, w charakterystycznym dla siebie szczerym i bezpośrednim stylu, powiedział: „Mam ochotę spytać, dlaczego - skoro ktoś z zewnątrz, tak jak ja, poświęcił życie poznawaniu, kochaniu i szerzeniu wiedzy oraz umiłowania tej wspaniałej tradycji, którą przyjął za swoją - nie robią tego ci, którzy się w niej urodzili? Czy marnuję tylko czas, czy któregoś dnia przebudzicie się i staniecie się tym, czym Kościół Boży nie tylko chce was widzieć, lecz wręcz nakazuje wam być" "41.

Długą noc prześladowań Kościół greckokatolicki na Ukrainie przetrwał dzięki świadectwu męczenników i wyznawców. Daru wolności nie zmarnuje, jeśli zrozumie, że w skarbcu tradycji oprócz rzeczy nowych, niezbędnych w dynamicznie zmieniającym się świecie, ma rzeczy stare, bez których przestanie być i stawać się tym, kim powinien (por. Mt 13, 52).

\footnotetext{
${ }^{39}$ R. TAFT, Liturgia, s. 260

${ }^{40}$ Tamże.

${ }^{41}$ Tamże, s. 261.
} 


\section{BIBLIOGRAFIA}

CONgregazione per Le Chiese Orientali, Istruzione per l'applicazione delle prescrizioni liturgiche del Codice dei Canoni delle Chiese Orientali, Libreria Editrice Vaticana, 1996.

De cultu mariano saeculis XVII-XVII, Romae: Academia Mariana Internationalis 1988.

Dictionnaire de théologie catholique, Dictionnaire de théologie catholique, red. Jean Michel Alfred Vacant, Eugène Mangenot, Émile Amann, t. VII, Paris: Letouzey et Ané 1927.

Dodatok do čynnostej y riszen 'ruskoho provincijalnoho sobora v Halyčyni otbuvšoho sja vo L'vovi wr. 1891, L'vov 1897.

Galadza Peter, The Theology and Liturgical Work of Andrei Sheptytsky (1865-1944), (Orientalia Christiana Analecta 272), Roma: Pontificio Istituto Orientale 2004.

Jan PaWel II, Adhortacja apostolska Ecclesia in Europa. O Jezusie Chrystusie, który żyje w Kościele, jako źródło nadziei dla Europy, 2003.

JAN PAWEe II, List Apostolski Orientale Lumen, 1995.

Kanony Partykuljarnoho Prava Ukrä̈n'koï Hreko-Katolyc ’koï Cerkvy. Specvypusk „Blahovisnyka Verchovnoho Archyjepyskopa Kyjevo-Halyc'koho Ukraïnskoï Hreko-Katolyc'koï Cerkvy 2015 roku”, Berezen' 2015, L'viv: Vydavnyctvo „Drukars`ki kunš'ty” 2015.

Katechyzm Ukrä̈ns'koji Hreko-Katolyc'koji Cerkvy „Chrystos - naša Pascha”, L'viv: Vydavnyctvo „Svičado” 2011.

Kodeks Kanonów Kościołów Wschodnich, Lublin: Wydział Prawa, Prawa Kanonicznego i Administracji Katolickiego Uniwersytetu Lubelskiego, Wydawnictwo Archidiecezji Lubelskiej „Gaudium” 2002.

Korolevsky Kyrylo (Jean Charon), Rym i obrjadovo-liturhični dyskusiï u Patrijaršij Kÿ̈vs `kij Vselens `kij Cerkvi miž dvoma Svitovymy vijnamy, red. Dmytro Blažejovs`kyj, L`viv 2002.

Molytvoslov, Rym-Toronto: Vydavnyctvo OO. Vasylijan 1990.

Przemówienie księdza kardynata Karola Wojtyty podczas wizytacji parafii greckokatolickiej w kościele św. Katarzyny w Krakowie, 1-5 listopada 1972 r., w: Włodzimierz MoKRY, Papieskie postania Jana Pawła II do Ukrainców, Wydawnictwo „Szwajpolt Fiol”, Kraków 2001.

RAES Alfonse, Le liturgicon ruthène depuis l'Union de Brest, „Orientalia Christiana Periodica” 7 (1942), № 1-2.

Sacra Congregazione Per la Chiesa Orientale, Oriente cattolico. Cenni storici e statistiche, Città del Vaticano 1962.

TAFT Robert F., Liturgia. Wzór modlitwy, ikona życia, Warszawa: Wydawnictwo Księży Marianów PROMIC, 2013.

\section{PROBLEMATYCZNY POWRÓT DO ŹRÓDEŁ: \\ NIEPOKALANE POCZECIE NAJŚWIETSZEJ MARYI PANNY \\ W LITURGII UKRAIŃSKIEGO KOŚCIOŁA GRECKOKATOLICKIEGO}

Streszczenie

Artykuł dotyczy jednego z najistotniejszych aspektów życia Katolickich Kościołów Wschodnich, jakim jest ich wierność własnemu obrządkowi, czyli liturgicznemu, teologicznemu, duchowemu i dyscyplinarnemu dziedzictwu (por. kan. 28 §1 Kodeksu Kanonów Kościołów Wschodnich). Magisterium Kościoła, od dokumentów Soboru Watykańskiego II do wydanej w 1996 r. przez Kongregację Kościołów Wschodnich Instrukcji w sprawie stosowania przepisów liturgicznych Kodeksu Kanonów Kościołów Wschodnich wzywa te wspólnoty do ponownego odkrycia bogactwa swojej tradycji, a gdzie zachodzi taka potrzeba - do roztropnego usunięcia 
obcych zapożyczeń i powrotu do źródeł. Na przykładzie święta celebrowanego na chrześcijańskim Wschodzie 9 grudnia widać, jak trudny jest ten proces w Ukraińskim Kościele Greckokatolickim. Rzymska reforma ksiąg liturgicznych (lata 40. XX wieku), która przywróciła zmienioną w $1891 \mathrm{r}$. nazwę i liturgię bizantyńskiego święta „Poczęcie św. Anny, gdy poczęła ona Najświętszą Bogurodzicę”, czeka na pełną recepcję i implementację.

Słowa kluczowe: Katolickie Kościoły Wschodnie; latynizacja; reforma liturgiczna; Kongregacja Kościołów Wschodnich; rok liturgiczny. 